\title{
Creating a Successful Transition for Working-Class First-Year Students
}

\author{
Krista M. Soria
}

This study explored differences between working-class and middle/upper-class first-year college students enrolled at large, public research universities. Results from administering the Student Experience in the Research University survey at 11 universities in 2010 $(n=23,331)$ suggest that working-class first-year students reported a less welcoming campus climate, lower academic engagement, higher academic disengagement, and fewer academic interactions with classmates compared with middle/upper-class students. Recommendations for first-year transition programs and new student orientation practitioners are discussed.

College students from lower socioeconomic backgrounds, including workingclass students, are less likely than their peers from middle/upper-class backgrounds to enroll in and graduate from higher education (Haveman \& Wilson, 2007; McDonough, 1997; Mortenson, 2007; Walpole, 2007). Working-class students who enroll at colleges and universities often encounter unique challenges in transitioning to their new academic environments. Most scholarship addressing the lower retention and completion rates of students from working-class backgrounds focuses on examining differences in students' social integration and sense of belonging at their colleges and universities (Lehmann, 2007). Several scholars have noted that working-class students are more likely to withdraw from higher education because the university life feels alien, they have problems connecting with their wealthier peers, and they experience significant challenges becoming integrated into the social life of the institution (Aries \& Seider, 2005; Granfield, 1991; Hurst, 2010; Lehmann, 2007; Stuber, 2011).

While previous studies have focused more explicitly on working-class students' social integration and sense of belonging, this paper explores differences between working-class and middle/upper-class students in other areas, including students' perceptions of campus climate, academic engagement, academic disengagement, and academic classmate interactions. Framed within the lens of Bourdieu's (1986) theory of social reproduction, this study examines working-class students' experiences on campuses where the majority of students self-identify as middle/ upper-class. Efforts that universities can take to support working-class students' transition into the academy can affect a positive change on students' persistence toward degree completion; therefore, this paper provides recommendations for first-year transition programs and new student orientation practitioners that can

Krista M. Soria (ksoria@umn.edu) is an Analyst in the Office of Institutional Research at the University of Minnesota. 
help working-class students to achieve greater success in higher education.

\section{Working-Class Students in Higher Education}

The majority of higher education research related to social class relies upon Bourdieu's (1986) theory of social reproduction to describe the experiences of working-class students. According to Bourdieu (1986), social class is a combination of economic capital (accumulated money or wealth), social capital (network of acquaintances), and cultural capital (knowledge or familiarity with the dominant culture). Research focusing on social class in higher education has been primarily concerned with Bourdieu's (1986) notion of "habitus," a "common set of subjective perceptions held by all members of the same group or class that shapes an individual's expectations, attitudes, and aspirations" (p. 9). Workingclass students leave behind their former working-class family habitus to join the new, more elite habitus of the middle-class university environment (Berger, 2000; Green, 2003; Hurst, 2010; Stuber, 2011). Reflective of middle-class values, culture, and customs, the higher education system contributes to the reproduction of middle and upper-class power by systematically excluding working-class students who do not fit into the middle/upper-class habitus of higher education. As a consequence, working-class students experience alienation and estrangement within the middle-class habitus of higher education (Beeghley, 2000; Goldthorpe, Llewellyn, \& Payne, 1987; Ostrove, 2003).

Issues relating to social class are principally ignored at many higher education institutions, often because many believe that social class is invisible on college campuses (McLaren \& Farahmandpur, 2001; Tokarczyk, 2004). Few colleges and universities include discussions of social class in diversity programming for new students or embed themes of social class in curricular and co-curricular content for students in transition to the university. For working-class students, the absence of social class in campus diversity can prove estranging and isolating-students who do not "see" themselves reflected in curricular and co-curricular programming may feel devalued, marginalized, and unaccepted.

Further compounding the challenges related to the absence of social class in campus programs, working-class students also experience challenges negotiating their social class identity in the middle-class culture of higher education (Hurst, 2010). According to Jensen (2004), the middle-class college culture of higher education does not "grant dual citizenship" (p. 178), thus obligating workingclass students to conform to middle-class cultural norms, in a way developing into "middle-class impersonators" (Langston, 1993, p. 69). Tying back to Bourdieu's (1986) social reproduction theory, working-class students may feel like outsiders in the middle-class habitus of higher education, yet are no longer as embedded in the working-class habitus of their family life. Amidst these challenges, workingclass students are, therefore, not likely to receive the institutional support they need to become acculturated to campus norms and values, nor the family support to remain engaged in their academic pursuits.

Programs addressing the needs of first-year students are ideally positioned 
to support working-class students as they transition to the middle-class academy. Several scholars have noted the benefits of student participation in first-year programs, including new student orientation. For example, Pascarella, Terenzini, and Wolfle (1986) found that orientation programs had a direct, positive effect on students' social integration and their subsequent commitment to the institution. Mayhew, Stipeck, and Dorow (2011) also found evidence that students' participation in orientation explains greater variance in their social adjustment than in their academic adjustment, further suggesting that some of the greatest benefits to orientation participation may lie within the social domains of campus life.

While extant literature supports the notion that new student orientation has a deep impact on students' social integration, there are also benefits related to students' academic integration as well. For example, Mayhew et al. (2011) found that orientation programs can enable students to adjust to the academic demands of college, understand professor's expectations, fully navigate campus services, manage their time effectively, and develop effective study skills. In addition, WolfWendel, Tuttle, and Keller-Wolff (1999) demonstrated that first-year participants in a summer institute orientation program believed that the program facilitated their academic and developmental transitions; furthermore, orientation programs have been demonstrated to improve retention and academic achievement (Beal \& Noel, 1980; Busby, Gammel, \& Jeffcoat, 2002; Green \& Miller, 1998).

The more informed new student orientation and first-year transition practitioners are about the needs of diverse and underrepresented students, the more intentional they can be in crafting programs to facilitate the successful transition of new students into campus. Gaining insights into working-class students' perception of campus climate and their academic engagement can, therefore, provide practitioners with insights into individual and institutional factors that may subsequently affect these students' retention. Correspondingly, this paper addresses the following research question: are there differences between working-class and middle/upper-class students with regard to their perceptions of campus climate, academic engagement, academic disengagement, and academic classmate interactions?

\section{Method}

\section{Instrument and Participants}

The Student Experience in the Research University (SERU) survey is based at the Center for Studies of Higher Education (CSHE) at the University of CaliforniaBerkeley. The SERU survey sampling plan is a census scan of the undergraduate experience: all undergraduates are included in this web-based questionnaire, with the majority of communication occurring by electronic mail. The SERU survey contains nearly 600 individual items focusing on students' academic engagement, civic engagement, global knowledge and skills, and development of academic, 
global, and inter-relational skills. In the survey, each student answers a set of core questions which focus on time use, evaluation of the student's major, campus climate, and satisfaction with his or her university experience.

In spring 2010, the SERU survey was administered to 269,754 undergraduate students across 11 large, public universities classified by the Carnegie Foundation as having very high research activity. The institutional level response rate for the survey was $35.8 \%(n=96,595)$. Of the total respondents, $23,331(24.1 \%)$ were first-year, non-transfer students who had been admitted in fall 2009. The first-year, non-transfer students were used in this analysis. Within the survey, students were asked to identify their social class through the question, "Which of the following best describes your social class when you were growing up?" Students could select one of the following categories: wealthy, upper-middle or professional-middle, middle-class, working-class, and low-income or poor. Students who identified as low-income or poor were removed from analysis, and the three middle/upperclass groups were condensed into one group. Table 1 demonstrates the number of first-year students who were used in the analysis; notably, working-class students in this study are more likely to be female, students of color, and first-generation as compared to middle/upper-class students.

TABLE 1

\section{Frequency of Demographic Variables}

\begin{tabular}{lrrrr} 
& Middle/Upper Class & \multicolumn{2}{c}{ Working-Class } \\
Variables & $n$ & $\%$ & $n$ & $\%$ \\
Male & 7649 & $41.4 \%$ & 1284 & $38.6 \%$ \\
Female & 10835 & $58.6 \%$ & 2040 & $61.4 \%$ \\
& & & & \\
American Indian or Alaskan Native & 92 & $.5 \%$ & 19 & $.6 \%$ \\
African American & 443 & $2.6 \%$ & 132 & $4.2 \%$ \\
Hispanic & 1559 & $9.3 \%$ & 809 & $25.7 \%$ \\
Asian, Filipino, or Pacific Islander & 5439 & $32.3 \%$ & 1318 & $41.8 \%$ \\
White & 8006 & $47.6 \%$ & 735 & $23.3 \%$ \\
Other/Unknown & 708 & $4.2 \%$ & 84 & $2.7 \%$ \\
International & 546 & $3.2 \%$ & 59 & $1.9 \%$ \\
& & & & \\
Non-First-Generation & 11056 & $86.2 \%$ & 1463 & $44.6 \%$ \\
First-Generation & 1766 & $13.8 \%$ & 1818 & $55.4 \%$
\end{tabular}




\section{Variables}

Within the survey, students were requested to respond to questions relating to their perception of campus climate for different groups of students; the frequency with which they participated in academic activities (including participating in classes and interacting with faculty); the frequency with which they turned in assignments late, skipped class, or went to class unprepared; and the frequency with which they interacted with classmates in academic activities, such as study groups or in completing class projects. Campus climate items began as follows:"Indicate how strongly you agree or disagree with each of the following statements." These items were coded one (strongly disagree) to six (strongly agree). Academic engagement, academic disengagement, and classmate interaction items began with the question, "During the academic year, how often have you done each of the following?" and were scaled one (never) to six (very often).

To obtain factors for these items, the researcher conducted a principal component analysis (PCA) on 19 items with oblique rotation (promax) for the first-year students only. The Kaiser-Meyer-Olkin measure verified the sampling adequacy for the analysis $(\mathrm{KMO}=.84)$. Bartlett's test of sphericity, which tests the null hypothesis that the correlation matrix is an identity matrix, was significant $\left(x^{2}(171)=148799.17, p<.001\right)$, indicating that correlations between items were sufficiently large for PCA. The researcher ran an initial analysis to obtain the variances extracted for each component in the data (eigenvalues); four components had an eigenvalue over Kaiser's criterion of one and explained $63.49 \%$ of the variance. Given the large sample size, Kaiser's criteria for components, and the convergence of a scree plot that showed inflexions that justify retaining four components, the final analysis retained the following factors: campus climate, academic engagement, academic disengagement, and frequency of classmate interactions.

Table 2 shows the factor loadings after rotation in a pattern matrix, with factor loadings over .40 in bold. The factor scores were computed using the regression method and saved as standardized scores with a mean of zero and a standard deviation of one. The factors ranged in their estimated internal reliability from Cronbach's $\alpha=.75$ to .92 (Table 2). 
TABLE 2

Summary of Factor Analysis Results for the SERU Questionnaire $(n=16,879)$

Item

Campus
Climate
$(\alpha=.92)$

Students are respected here

regardless of their race or ethnicity

Students are respected here

regardless of their religious beliefs

Students are respected here

regardless of their gender

Students are respected here

regardless of their sexual orientation

Students are respected here

regardless of their economic or social class

Students are respected here

regardless of their political beliefs

Students are respected here

regardless of their disabilities

Interacted with faculty during

lecture class sessions

Asked an insightful question in class

Contributed to a class discussion

Had a class in which the professor

knew or learned your name

Talked with the instructor outside

of class about issues and concepts

derived from a course

Communicated with a faculty

member by e-mail or in person

Gone to class unprepared

Gone to class without completing

assigned reading

Skipped class

.014

$-.035$

.005

Worked on class projects or studied

as a group with other classmates

outside of class

Helped a classmate better understand

$-.001$

.793

.004

$-.010$

.032

.030

$-.057$

.011

$-.019$

.034
Academic

Engagement

$(\alpha=.84)$

.016

$-.020$

.001

.035

$-.009$

$-.030$

$-.001$

.020

$-.030$

.024

.809

.798

.034

.765

$-.002$

.728

$-.006$

$-.019$

.706

.673

$-.016$

.851

.797

$-.059$

$-.051$

.735

the course material when studying together
.627

.008

.196

.003

$-.009$
Academic

$(\alpha=.75)$

003

\section{8} .000 .008 010 
To address the research question framing this study, the researcher analyzed the data using analysis of variance (ANOVA) to determine whether there were statistically significant differences between working-class and middle/upper-class first-year students with regard to students' perceptions of campus climate, academic engagement, academic disengagement, and classmate interactions. The results suggest that first-year working-class students experience a less welcoming campus climate, lower academic engagement, higher academic disengagement, and fewer classmate interactions as compared to their middle/upper-class peers (Table 3 ). The effect size of the differences, as measured by Cohen's $d$, suggests the differences are modest in most cases, with the largest differences occurring in students' academic engagement and perceptions of campus climate.

TABLE 3

\section{Differences between Working-Class and Middle/Upper-Class Students}

\begin{tabular}{|c|c|c|c|c|c|c|}
\hline & $\begin{array}{c}\text { Middle/Upper } \\
\text {-Class }\end{array}$ & $\begin{array}{l}\text { Working } \\
\text {-Class }\end{array}$ & & & & \\
\hline Factors & $M(S D)$ & $M(S D)$ & $95 \%$ CI & $d f$ & $F$ & $d$ \\
\hline Campus Climate & $.05(.97)$ & $-.09(1.02)$ & $(-.12,-.03)$ & 15480 & $51.02 * * *+$ & .14 \\
\hline Academic Engagement & $.06(.99)$ & $-.14(.99)$ & $(-.18,-.11)$ & 15480 & $100.36^{* * *}$ & .20 \\
\hline Academic Disengagement & $-.02(.98)$ & $.03(1.01)$ & $(-.01, .06)$ & 15480 & $4.57^{*}+$ & -.05 \\
\hline Classmate Interactions & $.03(1.00)$ & $-.09(.99)$ & $(-.12,-.05)$ & 15480 & $37.25^{* * *}$ & .12 \\
\hline
\end{tabular}

Note. ${ }^{*} \mathrm{p}<.05,{ }^{* *} \mathrm{p}<.01,{ }^{* * *} \mathrm{p}<.001,+$ Equal Variances not Assumed Using Levene's Test

\section{Discussion and Recommendations}

This study found that working-class students experience a less welcoming campus climate as compared to their middle/upper-class peers. The campus climate factor included questions related to the campus climate for students based on gender, socioeconomic status or social class, race, political and religious beliefs, sexual orientation, and disabilities. Additionally, the results suggest that workingclass students have lower academic engagement, which included items related to the frequency with which students contributed to class discussion and interacted with faculty inside and outside of class. Working-class students also reported higher academic disengagement, which included turning in assignments late, attending class unprepared, and skipping classes. Finally, working-class students reported 
having fewer interactions with classmates in academic activities, including working on group projects outside of class.

The results demonstrate some vital areas in which first-year coordinators, orientation directors, or transition specialists can positively impact working-class students' transition into higher education. First, the researcher recommends that all practitioners actively work to make social class visible in first-year programs such as new student orientation or in first-year courses. Working-class students may internalize their struggles because social class is relatively invisible on college campuses. Student affairs practitioners can make social class visible by talking openly about privilege, class power, and ambivalence about working-class identity issues (Clawson \& Leiblum, 2008; Granfield, 1991). As noted by Oldfield (2007), campus practitioners should encourage all students to become aware of class on campus, as "it is equally important that we change the campus environment to be inclusive so that privileged students are encouraged to understand and appreciate the values reflected in poor and working-class students' ways of life" (p. 9). Among other themes of diversity in new student programming, themes related to social class issues should be predominant, and working-class students' identities should be acknowledged and affirmed.

First-year program directors and other student affairs practitioners on campus should consider social class as a dimension not to be overlooked when examining the campus climate for underrepresented students. The needs of working-class students should not be marginalized, but instead brought to the forefront of conversations related to the experiences of underrepresented students on campusespecially the campus climate for these students. Lasting impressions of campus climate can be shaped during new student orientation; therefore, it is vital that practitioners reflect upon their own practices in orientation programming that may alienate working-class students. While many campuses have adopted models that require students to pay for their orientation experiences, few may either offer scholarships or target available scholarships to working-class students.

Additionally, first-year transition and new student orientation practitioners are encouraged to consider offering summer bridge programs directed at meeting the needs of working-class students. As this study found that working-class students are also likely to be students of color and first-generation students, broader bridge programs that incorporate these facets of students' identities can prove beneficial for many students. Barratt (2011) encouraged institutions to build bridge programs for incoming working-class students that balance their acquisition of social and academic capital. Bridge programs can help first-year working-class students to experience a welcoming campus climate even before traditional classes begin and further enhance their sense of belonging through the early development of faculty and classmate interactions.

Within larger institutions (as is the context of this present study), bridge programs can also help working-class students connect with academic advisors who can serve as supporters and mentors during students' first year of study. Academic advisors can aid working-class students with acculturating to the new social and cultural norms of campus, while still maintaining and valuing their 
social class identities. Hurst (2010), Stuber (2011), and Granfield (1991) found that many working-class students, in their qualitative studies, spoke with pride about the values they learned growing up in working-class families, including having developed a strong work ethic and discipline for task completion. These are values that can support working-class students as they make transitions to higher education-with support and encouragement from advisors, working-class students can integrate these cultural norms and values without feeling pressure to completely assimilate in the middle-class culture of higher education.

As many working-class students are likely to be first-generation students, the challenges facing working-class students may be partially derived from the fact that their parents may not provide the support they need to become academically engaged in their coursework. According to Engle and Tinto (2008), research has demonstrated that first-generation and low-income students (many of whom are also likely to be working-class students) are less likely to be engaged in the types of academic and social experiences that foster success in college, such as studying in groups, interacting with faculty and other students, and using support services. Others have found that first-generation students are less confident in their academic ability and readiness for college-level work and are also more likely to avoid asking questions or seeking help from faculty (Jenkins, Miyazaki, \& Janosik, 2009). Collier and Morgan (2008) found that first-generation students tended to grapple with confusion over faculty expectations for assignments and disciplinespecific academic expectations, in addition to general challenges understanding and fulfilling the "college student role" (p. 441).

First-year transition and new student orientation practitioners can counteract those findings above by actively working to enhance the academic adjustment of working-class students. First, these professionals can encourage working-class students to connect with faculty inside and outside of class and help students to develop confidence in speaking with faculty about academic matters. New student professionals can serve as mentors and guides to working-class students, helping them to navigate new territory with regard to academic norms and expectations. Additionally, new student professionals can help working-class students to connect with other students in study groups by helping students to locate study spaces on campus, helping students to form study groups within classes, or working with others on campus (such as residence hall professionals) to ensure that adequate study space is available in alternative locations.

Finally, first-year transition and new student orientation practitioners can dig deeper into the experiences of working-class students to learn more about the barriers these students face with regard to becoming academically engaged on campus. This study suggests that working-class students are more likely to be academically disengaged, meaning they are more likely to attend class unprepared or without completing assigned reading, skip classes, and turn in assignments late. Seeking evidence for the potential factors underlying those trends can help practitioners and administrators to mitigate the causes of students' academic disengagement. 


\section{Limitations and Conclusion}

Generalizability to other institutions may be limited, as the institutional context of this study only includes large, public research universities. Additionally, the study relied upon students' self-identified social class; due to students' individual interpretation of their class status, their self-identification could change in different contexts or across time. Finally, the study only examined students at one point in time; future longitudinal or cross-sectional research could reveal additional insights into the experiences of working-class students not captured here.

In conclusion, this study found that working-class first-year students experience a less welcoming campus climate, lower academic engagement, higher academic disengagement, and fewer academic interactions with classmatesfactors suggesting that working-class college students experience greater challenges in becoming integrated within the middle-class habitus of higher education (Bourdieu, 1986), where middle/upper-class students make up the majority of the student population; furthermore, working-class students may not be as academically engaged on their campuses and experience greater disengagement from academics, suggesting the presence of factors that may impede their academic success. Finally, working-class students may not be as likely as their middle/upperclass peers to engage with their classmates in academic tasks. Issues of social class should be brought to the forefront of institutional planning for first-year students, and the needs of working-class students should continue to be addressed through campus-wide efforts to engage students. Through these measures, creating a more welcoming space for students on college campuses can help to enhance workingclass students' retention and degree completion.

\section{References}

Aries, E., \& Seider, M. (2005). The interactive relationship between class identity and the college experience: The case of lower income students. Qualitative Sociology, 28(4), 419-443.

Barratt, W. (2011). Social class on campus: Theories and manifestations. Sterling, VA: Stylus.

Beal, P. E., \& Noel, L. (1980). What works in student retention: The report of a joint project of the American College Testing program and the National Center for Higher Education Management Systems. Washington, DC: NCHEMS.

Beeghley, L. (2000). The structure of social stratification in the United States. Fourth Edition. Boston, MA: Pearson.

Berger, J. B. (2000). Optimizing capital, social reproduction, and undergraduate persistence: A sociological perspective. In J. M. Braxton (Ed.), Reworking the student departure puzzle (pp. 95-124). Nashville, TN: Vanderbilt University Press. 
Bourdieu, P. (1986). The forms of capital. In J. Richardson (Ed.), Handbook of theory and research for the sociology of education (pp. 241-258). Westport, CT: Greenwood Press.

Busby, R. R., Gammel, H. L., \& Jeffcoat, N. K. (2002). Grades, graduation, and orientation: A longitudinal study of how new student programs relate to point averages and graduation. The Journal of College Orientation and Transition, 10(1), $45-57$.

Clawson, D., \& Leiblum, M. (2008). Class struggle in higher education. Equity \& Excellence in Education, 41(1), 12-30.

Collier, P. J., \& Morgan, D. L. (2008). "Is that paper really due today?": Differences in first-generation and traditional college students' understandings of faculty expectations. Higher Education, 55, 425-446.

Engle, J., \& Tinto, V. (2008). Moving beyond access: College for low-income, firstgeneration students. Washington, DC: The Pell Institute Retrieved May 11, 2011, from http://www.pellinstitute.org/files/COE MovingBeyondReport Final.pdf.

Goldthorpe, J. H, Llewellyn, C., \& Payne, C. (1987). Social mobility and class structure in modern Britain. New York, NY: Clarendon Press.

Granfield, R. (1991). Making it by faking it. Journal of Contemporary Ethnography, $20,331-351$.

Green, A. (2003). Learning to tell stories: Social class, narratives, and pedagogy. Modern Language Studies, 33(1/2), 80-89.

Green, J. T., \& Miller, M. T. (1998). A comparison study of enrollees and nonenrollees in an orientation course at a two-year college. The Journal of College Student Orientation and Transition, 5(2), 14-18.

Haveman, R., \& Wilson, K. (2007). Access, matriculation, and graduation. In S. Dickbert-Conlin \& R. Rubenstein (Eds.), Economic inequality and higher education: Access, persistence, and success (pp. 17-43). New York, NY: Russell Sage Foundation, Inc.

Hurst, A. L. (2010). The burden of academic success: Loyalists, renegades, and double agents. New York, NY: Rowman \& Littlefield.

Jenkins, A. L., Miyazaki, Y., \& Janosik, S. M. (2009). Predictors that distinguish first-generation college students from non-first generation college students. Journal of Multicultural, Gender, and Minority Studies, 3(1), 1-9.

Jensen, B. (2004). Across the great divide: Crossing classes and clashing cultures. In M. Zweig (Ed.), What's class got to do with it? (pp. 168-184). Ithaca, NY: Cornell University Press.

Langston, D. (1993). Who am I now? The politics of class identity. In M. M. Tokarczyk \& E. A. Fay (Eds.), Working-class women in the academy: Laborers in the knowledge factor (pp. 3-24). Amherst, MA: University of Massachusetts Press.

Lehmann, W. (2007). "I just didn't feel like I fit in:" The role of habitus in university drop-out decisions. Canadian Journal of Higher Education, 37(2), 89-110.

Mayhew, M. J., Stipeck, C. J., \& Dorow, A. J. (2011). The effects of orientation programming on learning outcomes related to academic and social adjustment with implications for transfers and students of color. Journal of the First-Year Experience \& Students in Transition, 23(2), 53-75. 
McDonough, P. M. (1997). Choosing colleges: How social class and schools structure opportunity. Albany, NY: State University of New York Press.

McLaren, P., \& Farahmandpur, R. (2001). Teaching against globalization and the new imperialism: Toward a revolutionary pedagogy. Journal of Teacher Education, 52(2), 136-150.

Mortenson, T. (2007). Bachelor's degree attainment by age 24 by family income quartiles, 1970 to 2005. Oskaloosa, IA: Postsecondary Education Opportunity.

Pascarella, E. T., Terenzini, P. T., \& Wolfle, L. (1986). Orientation to college and freshman year persistence/withdrawal decisions. Journal of Higher Education, $57,155-175$.

Oldfield, K. (2007). Humble and hopeful: Welcoming first-generation poor and working-class students to college. About Campus, 11(6), 2-12.

Ostrove, J. M. (2003). Belonging and wanting: Meanings of social class background for women's constructions of their college experiences. Journal of Social Issues, 59(4), 771-784.

Stuber, J. M. (2011). Inside the college gates: How class and culture matter in higher education. Lanham, MD: Lexington Books

Tokarczyk, M. M. (2004). Promises to keep: Working class students and higher education. In Zweig, M. (Ed.). What's class got to do with it? American society in the twenty-first century. (pp. 161-168). Ithaca, NY: Cornell University Press.

Walpole, M. (2007). Economically and educationally challenged students in higher education: Access to outcomes. ASHE Higher Education Report, 33(3). San Francisco, CA: Jossey-Bass.

Wolf-Wendel, L. E., Tuttle, K., and Keller-Wolff, C. M. (1999). Assessment of a freshman summer transition program in an open-admissions institution. Journal of the First-Year Experience \& Students in Transition, 11(2), 7-32. 